\title{
Structural and Biochemical Features of Human Serum Albumin Essential for Eukaryotic Cell Culture
}

\author{
Vibhor Mishra * and Richard J. Heath \\ Protein Production Facility, Shared Resource Center, St. Jude Children's Research Hospital, \\ Memphis, TN 38105, USA; Richard.Heath@stjude.org \\ * Correspondence: Vibhor.Mishra@stjude.org
}

Citation: Mishra, V.; Heath, R.J. Structural and Biochemical Features of Human Serum Albumin Essential for Eukaryotic Cell Culture. Int. J. Mol. Sci. 2021, 22, 8411. https:// doi.org/10.3390/ijms22168411

Academic Editor: Alessandra Di Masi

Received: 30 June 2021

Accepted: 4 August 2021

Published: 5 August 2021

Publisher's Note: MDPI stays neutral with regard to jurisdictional claims in published maps and institutional affiliations.

Copyright: (c) 2021 by the authors. Licensee MDPI, Basel, Switzerland. This article is an open access article distributed under the terms and conditions of the Creative Commons Attribution (CC BY) license (https:// creativecommons.org/licenses/by/ $4.0 /)$.
Abstract: Serum albumin physically interacts with fatty acids, small molecules, metal ions, and several other proteins. Binding with a plethora of bioactive substances makes it a critical transport molecule. Albumin also scavenges the reactive oxygen species that are harmful to cell survival. These properties make albumin an excellent choice to promote cell growth and maintain a variety of eukaryotic cells under in vitro culture environment. Furthermore, purified recombinant human serum albumin is mostly free from impurities and modifications, providing a perfect choice as an additive in cell and tissue culture media while avoiding any regulatory constraints. This review discusses key features of human serum albumin implicated in cell growth and survival under in vitro conditions.

Keywords: human serum albumin; cell culture; ligand binding

\section{Introduction}

Albumins are globular proteins commonly found in blood plasma, egg white, milk, and plants [1-4]. Serum albumin is the most abundant protein in the blood plasma of all vertebrates [5]. It is synthesized in the liver as pre-pro-albumin and matures in the endoplasmic reticulum and the Golgi bodies before being secreted from the hepatocytes $[5,6]$. Human serum albumin (HSA) has a plasma concentration of 35-50 mg/mL [6,7], an approximate half-life of 19 days, and it is present in both extravascular and intravascular spaces $[7,8]$. Albumin performs a variety of essential functions. It regulates the oncotic pressure and $\mathrm{pH}$ of the blood [5]. It also binds and transports various bioactive molecules, including proteins, peptides, fatty acids, hormones, amino acids, drugs, nutrients, and metal ions $[6,9]$. These properties make albumin an excellent candidate for several clinical and biotechnological applications.

HSA is clinically used in hemorrhagic shock due to excessive blood loss, hypovolemia, hypoproteinemia, and fetal erythroblastosis $[6,10]$. In addition, purified HSA is commonly used in eukaryotic cell culture practices [11,12]. The past decade has seen HSA been extensively explored as a nanoparticle for targeted drug delivery [13]. For all these applications, large quantities of HSA are classically sourced from blood serum. However, recombinant HSA from heterologous sources such as Pichia pastoris, Saccharomyces cerevisiae, Escherichia coli, Kluyveromyces lactis, transgenic animals, and plants have proven to be most beneficial for biotechnological purposes [14-22].

Albumins are extensively used as drug delivery vehicles for various ailments due to their high serum concentration, long half-life, frequent recirculation, abundant accumulation in benign and malignant tissue types, non-toxicity, and non-immunogenicity $[8,23,24]$. Albumin quickly diffuses across leaky blood vessels in tumors, making it ideal for carrying anticancer drugs [24]. A large and diverse variety of drug molecules can be very effectively bound to the albumin-based nanoparticles (NP) $[13,25]$. These albumin NPs have been shown to have high drug entrapment capacity, controlled release, and high biocompatibility, and they are also biodegradable $[13,25]$. Moreover, albumin NPs are designed for efficient 
drug loading [26]. The NP can also accommodate surface modifications for improved drug binding, solubility, and enhanced drug targeting in a controlled fashion [13]. The conjugation of drugs to the albumin can be achieved by covalently linking the therapeutic compound to the $\mathrm{N}$ - or $\mathrm{C}$-terminus of the protein or any other unique amino acid of albumin using click chemistry, recombinant DNA technology, chemical cross-linking, or non-covalent interaction $[24,27,28]$.

Traditionally, fetal bovine serum (FBS) was a critical factor in eukaryotic cell cultures. It provides essential elements required for the desired growth of cells under in vitro conditions [11]. A crucial factor in FBS is bovine serum albumin (BSA), which accounts for $>95 \%$ of the protein content of the serum, along with small amounts of other proteins, including insulin, hormones, and growth factors. However, being a biological product, FBS exhibits significant batch-to-batch variability. It is often found to be contaminated by pathogens such as mycoplasmas, viruses, and prions responsible for transmissible spongiform encephalopathies (TSE). Therefore, there is a desire to avoid the use of serum, especially among those growing cells in a Good Manufacturing Practice (GMP) environment. Nowadays, purified recombinant albumin from heterologous sources has replaced serum in the cell culture media due to increasing regulatory concerns and quality control $[29,30]$. In addition, the structural similarities between albumins from different vertebrate sources allow them to be swapped in cell cultures to attain comparable results [11]. Consequently, bovine serum albumin (BSA) is more frequently used than HSA as its production is more cost-effective [31].

The action of albumin in cell culture is primarily dependent on its antioxidant properties, toxin sequestering properties, and transportation of bioactive ligands. This review highlights the inherent structural and biochemical features that allow human serum albumin (HSA) to be exploited for cell culture applications.

\section{Recombinant HSA}

Classically, HSA was commercially produced by fractionating human plasma [32]. However, human plasma always has a limited supply. In addition, inconsistencies in the quality of the raw material from different sources and other contamination issues lead to variations in the quality and quantity of the final purified protein.

Recombinant DNA technology has played a crucial role in the large-scale production of high-quality recombinant HSA (rHSA) [12]. Yeast, in particular, Pichia pastoris, is the most promising source for rHSA production, with easy scale-up of the cell culture to 5000-7500 L [15,33-36]. Yeast cells provide several post-translational modifications such as proteolytic processing, folding, and disulfide bond formation and can be genetically manipulated to avoid undesirable post-translational modifications [6]. Secretion of the protein into culture media lowers the number of downstream purification steps [15]. A series of ion exchange and hydrophobic chromatographic resins are used to clean up the recombinant albumin to attain desired purity $[15,37]$.

Plant seed bioreactors are another promising method for recombinant albumin production. Recombinant HSA can be produced in Oryza sativa seeds $[14,38,39]$. The expression level of the rHSA can be at least $0.3 \%$ based on the rice grain's weight. rHSA produced in this manner is structurally and functionally equivalent to plasma-derived HSA [14]. rHSA is also stably produced to $0.7 \%$ of total soluble protein in transgenic tobacco cell suspension culture [16]. Similar to yeast, in this approach, the recombinant protein is secreted into the cell culture media. The media is further subjected to downstream chromatographic processes to achieve desired purity [16]. 
Heterologous prokaryotic expression hosts have been used for rHSA expression and purification, with only moderate success due to the large size and many required disulfide bonds. Suboptimal processing of the recombinant albumin peptide due to lack of the eukaryotic protein folding machinery results in misfolded protein. Minimal secretion of the recombinant albumin is achieved from Bacillus subtilis as higher levels of expression overwhelm the secretion pathway [40]. In Escherichia coli, rHSA tends to accumulate as unfolded, insoluble aggregates in inclusion bodies, requiring denaturation and refolding to obtain a suitably active product [19]. These factors are major bottlenecks that increase the number of purification steps, production cost, and highly stringent quality control to achieve the desired quality and quantity of recombinant HSA. Co-expression of rHSA in E. coli along with the chaperone proteins can increase the amount of rHSA expressed in the soluble fraction from $10 \%$ to $60 \%$ [18] and this protein appears to be monomeric and structurally similar to HSA purified from plasma [41]. Some success has also been achieved by engineering HSA as a fusion protein with maltose-binding protein (MBP). Co-expression with protein disulfide isomerase enhances the recombinant protein's solubility [19].

\section{Structural and Biochemical Features of HSA}

HSA is encoded by a single gene mapped on the long arm of chromosome 4 at position q13.3 [7]. Hepatocytes synthesize albumin as pre-pro-albumin [42]. This pre-mature form of the protein has a 24 amino acid $\mathrm{N}$-terminal extension [43]. These $24 \mathrm{~N}$-terminal amino acids facilitate transport into the endoplasmic reticulum. Once inside, the first 18 amino acids are cleaved to make pro-albumin [43]. This pro-albumin is the primary intracellular form of albumin before it gets transported into the Golgi apparatus. The remaining six amino acids are cleaved from the $\mathrm{N}$-terminus by furin, and the mature albumin is secreted from the hepatocytes [43]. The mature human albumin consists of 585 amino acids and has a molecular mass of 66,348 Da.

HSA is a globular, heart-shaped protein with a repeating series of six helical subdomains [44,45]. HSA is comprised of $67 \% \alpha$-helices, $10 \%$ turns, $23 \%$ random coils, and no $\beta$-sheets [46]. High-resolution X-ray crystallography structures show three predominant domains in albumin. They are generally numbered as domain I (1-195 aa), domain II (196-383 aa), and domain III (384-585 aa) [44] (Figure 1). Each domain is subdivided into two subdomains, A and B. There is a remarkable degree of sequence and structural similarity as well as surface charge distribution similarity between HSA and its counterparts from bovine (BSA), equine (ESA), leporine (LSA), and canine (CSA) sources (Figure 2) [47-49]. At a sequence level, HSA and BSA share $76 \%$ identity [50], while, overall, serum albumins from various sources share more than $62 \%$ sequence identity [48]. The average root mean square deviation (RMSD) of BSA crystal structure compared to HSA structure is $1.1 \AA$; for ESA and LSA, it is $1.2 \AA$ [48]. This structural similarity is one of the main reasons HSA can be substituted with BSA or albumins from other sources in cell culture practices [11]. Molecular dynamics analysis of HSA, BSA, and CSA indicate that motion of domains I and III are key in defining the properties of the albumins [49]. BSA is structurally somewhat more rigid than HSA, while CSA is more flexible and possesses larger, more water-accessible drug binding sites. 


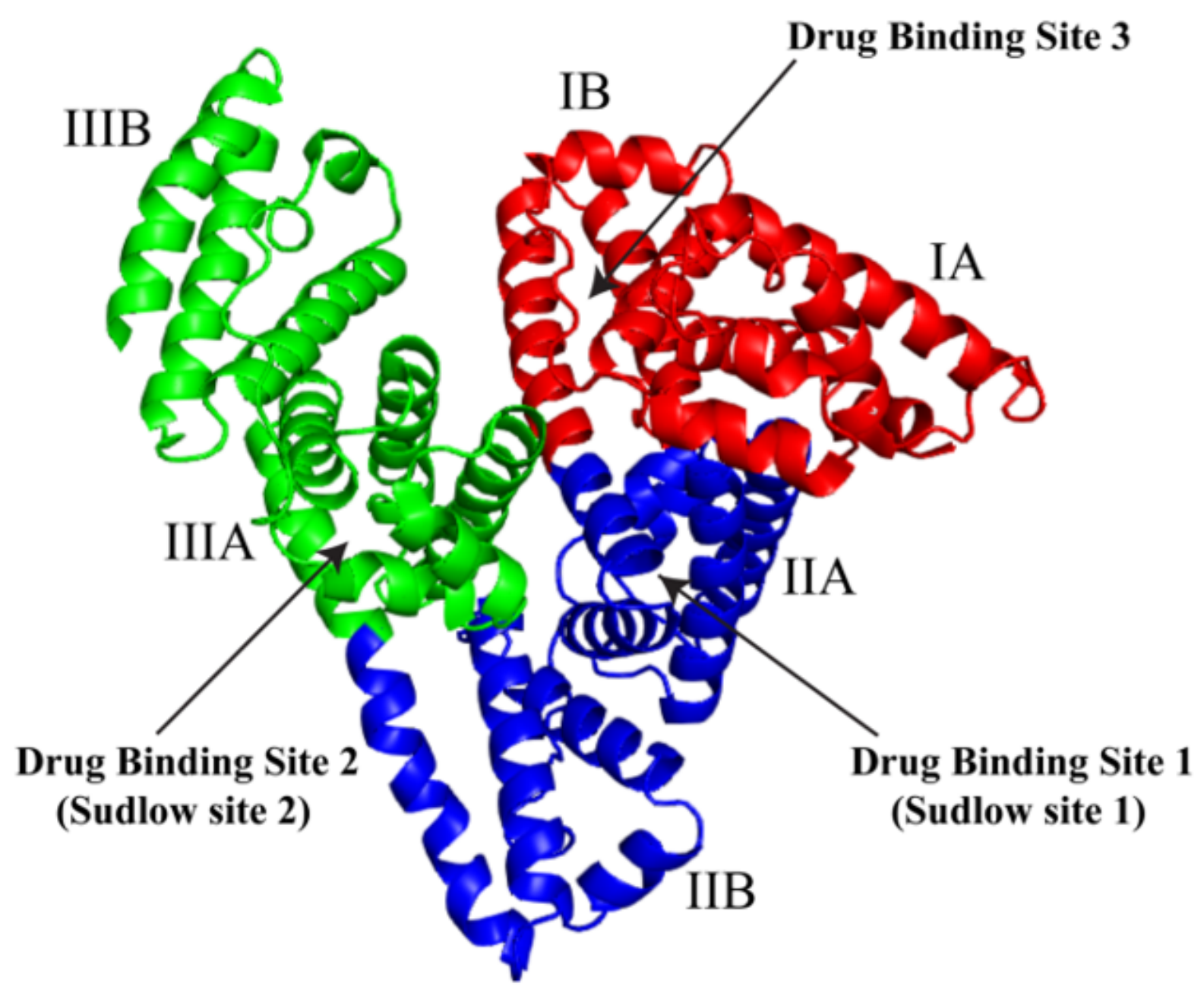

Figure 1. Domain organization of human serum albumin. Domain I (red), domain II (blue), and domain III (green). The 3-D model was generated by PyMOL using 1AO6 PDB file.

HSA has 17 intramolecular disulfide bridges that are present primarily between the $\alpha$-helices. These disulfide bonds are essential for the stability of the protein [51]. It also has one free cysteine residue (Cys-34), present in domain I and conserved across species. This residue is responsible for albumin dimerization during purification by forming an intermolecular disulfide bridge [44]. Chemical modification of Cys-34 can prevent dimer formation [52]. Purification of only domain I also results in protein dimerization because of this free cysteine residue [53]. The free cysteine residue is in a $\approx 10 \AA$ deep crevice and plays a critical role in the redox properties of albumins shown to be crucial in cell culture [11]. Cys34 forms complexes with various metal ions and scavenges free radicals under in vivo and in vitro conditions [11]. The Cys-34 residue is also involved in scavenging the free radical nitric oxide and other reactive oxygen species (ROS) [54]. It is attributed to protection against lipid peroxidation by reactive oxygen species by scavenging ROS [55]. Additionally, a conserved histidine residue (His-3) also acts as a critical metal chelator that scavenges reactive oxygen species [56]. 


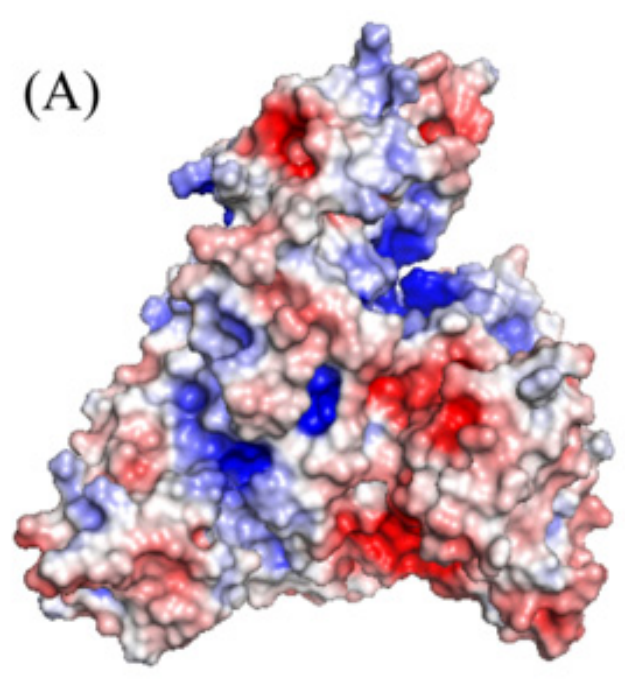

(C)

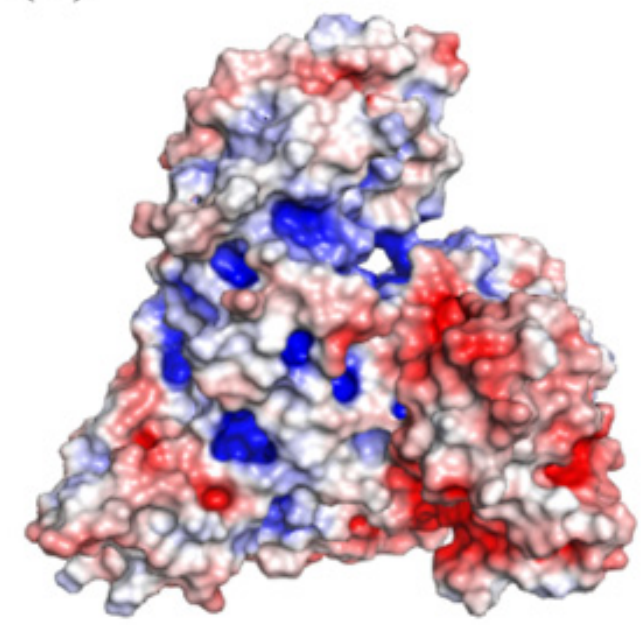

(B)

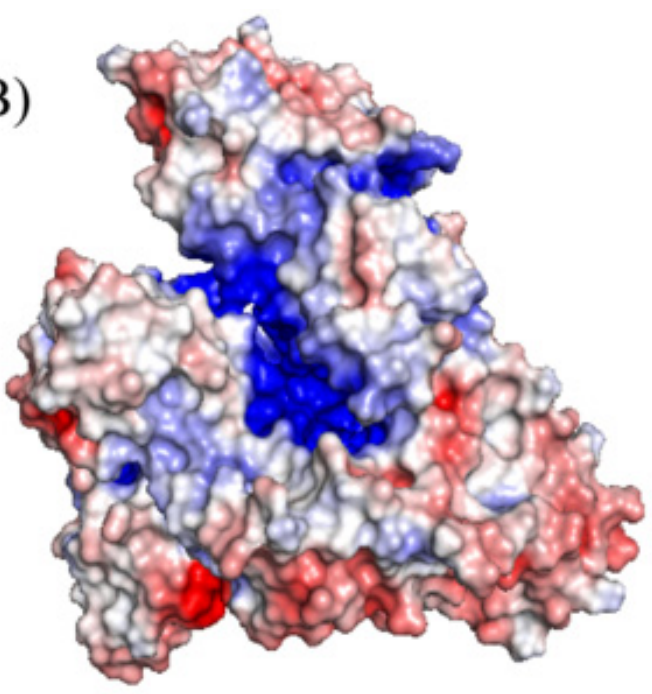

(D)

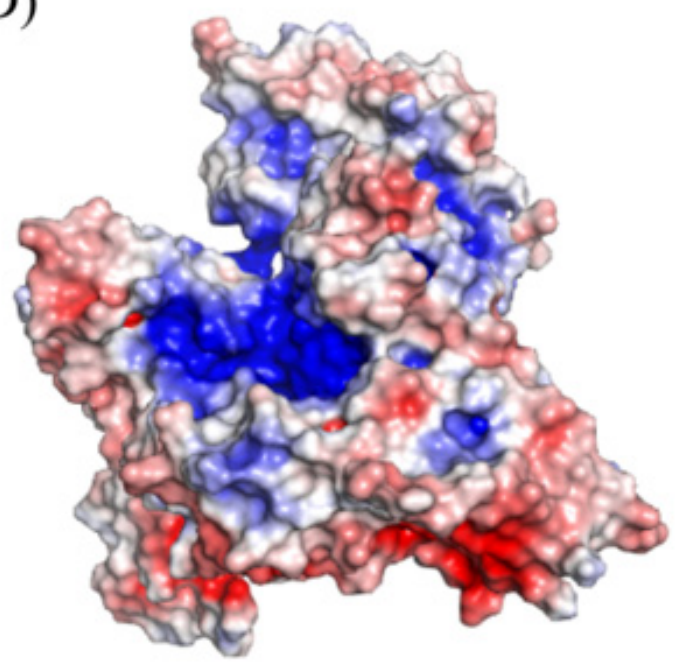

Figure 2. A comparison of surface charge distribution between HSA $(\mathbf{A}, \mathbf{B})$ and BSA $(\mathbf{C}, \mathbf{D})$. The two views for each protein structure are flipped $180^{\circ}$ along the vertical axis. The images were generated by PyMOL using 1AO6 and 4F5S PDB files.

\section{Fatty Acid Interactions}

HSA binds and carries fatty acids in the vascular system [57]. Albumin is the carrier of $99 \%$ of non-esterified fatty acid (FA) present in blood plasma. Classically, albumin is shown to have 7 high- and more than 20 low-affinity FA-binding sites [6,58]. FA affinity to albumin is also chain length-dependent, with oleate (16 carbons) having a higher affinity than laurate (10 carbons) [59]. FA binding modulates conformational changes in albumin [60]. Defatted albumin is present in a specific conformation know as $\mathrm{N}$-form (neutral-form) [61]. The FA bound form of albumin is known as B-form (basic-form) [58,61]. These forms have also been observed as FA-free HSA undergoes reversible conformational transitions at different $\mathrm{pH}$ values [62,63]. At $\mathrm{pH}$ of lower than 3, HSA has an extended conformation [63,64]. Between $\mathrm{pH} 3$ to 4.3 , HSA assumes a fast migrating (F) form characterized by increased viscosity and lower solubility [63]. Between $\mathrm{pH} 4.3$ and 8.0, the $\mathrm{N}$-form is represented by the characteristic heart-shaped structure (Figure 1) [63]. At a pH greater than 8.0, HSA is present as the B-form [63]. The transition from $\mathrm{N}$ to $\mathrm{B}$ forms is characterized by domain rotation within the molecule; domains I and III in particular appear to pivot around a point 
close to the interface with domain II [58]. The most distal subdomains display the most significant deviations in position as a consequence of FA binding [58].

The seven high-affinity FA binding sites are asymmetrically distributed throughout the protein [65-67] (Figure 3). The first site is located in subdomain IB. This FA binding site also binds with heme, sequestering free heme in the blood and subsequently recirculating it. The second FA-binding site lies at the interface between IA and IIA. FA-binding sites three and four are present in subdomain IIIA. These FA bind sites are also therapeutic compound binding hotspots [68]. The FA-binding site five is present in IIIB. Site six is between subdomains IIA and IIB, and site seven is present in subdomain IIA. NMR studies show sites two, four, and five are the primary FA interacting sites. They offer the most favorable conditions by providing a highly enclosed environment that allows the aliphatic chain of the FA to be tightly bound. Additionally, the presence of basic amino acid side chains at the binding pockets edge leads to salt bridge interactions with the fatty acyl carboxylic head group [58].

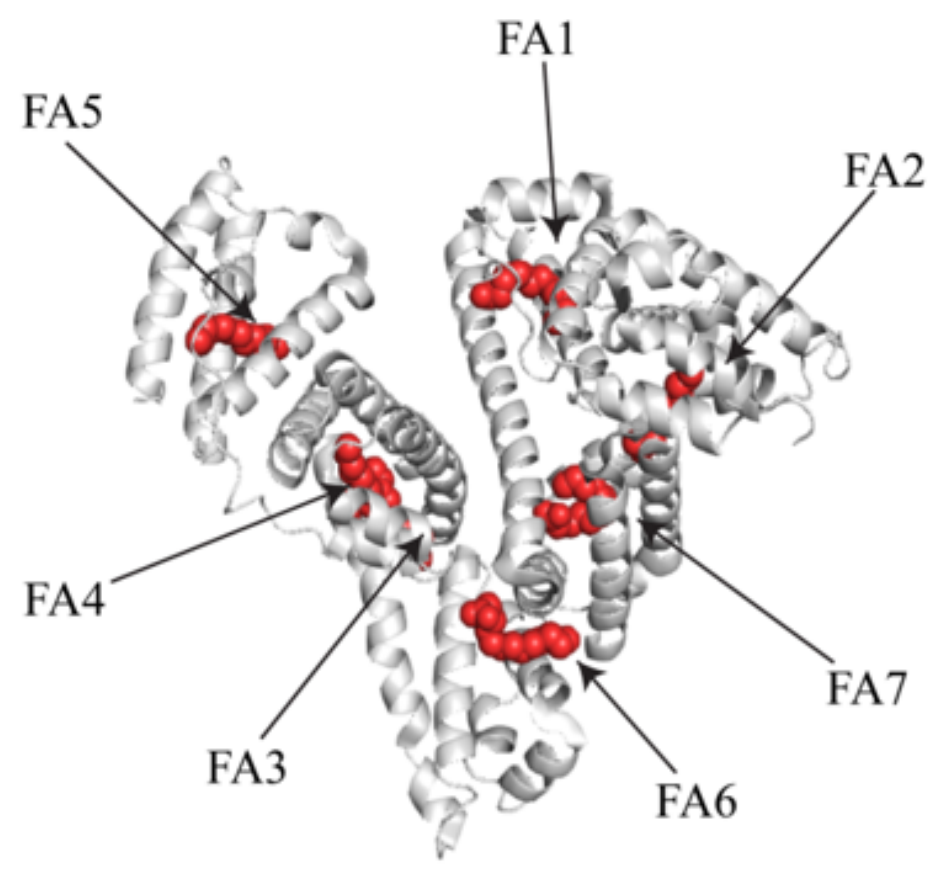

Figure 3. 3-D model of HSA showing the seven fatty acid (FA) binding sites. Myristate occupying the seven sites is rendered in red spheres. The 3-D model was generated by PyMOL using $1 \mathrm{HK} 4$ PDB file.

FA binding sites also accommodate other ligands, including several drug molecules [58]. Albumins from different species, such as human, bovine, and equine, are structurally similar, with similar amino acid compositions within the FA binding sites [47]. In eukaryotic cell culture systems, albumins present in the media bind with the FAs, circulate them, and help facilitate the FA uptake by the cells [6].

\section{Metal Ion Interactions}

Metal ions are essential for the growth and development of cells [69]. HSA is a key transporter of the crucial metal ions $\mathrm{Cu}^{2+}$ and $\mathrm{Zn}^{2+}$ in plasma [70]. In addition, metal ions such as copper undergo univalent redox reactions that catalyze the formation of free radicals [71]. It has been shown both in vivo and in vitro conditions that the potential toxic activity of metal ions is mitigated by albumin binding [6]. Albumin has four metal-binding sites with partially selective metal affinity preferences [6,72]. 


\subsection{The N-Terminus Metal-Binding Site (NTS)}

The first metal-binding site comprises the first three residues (Asp-Ala-His in HSA) at the N-terminus of the protein $[6,72,73]$. The nitrogen atoms of the peptide bonds between these residues, the N-terminal amine and His-3 residue, coordinate with the $\mathrm{Cu}^{2+}$ and $\mathrm{Ni}^{2+}$ metal ions in a square planar ligand arrangement $[6,73,74] . \mathrm{Cu}^{2+}$ binds with high affinity to albumin, with the dissociation constant for the HSA- $\mathrm{Cu}^{2+}$ complex being $6.7 \times 10^{-17} \mathrm{M}$ [75]. The His-3 residue is considered critical for the high-affinity binding of $\mathrm{Cu}^{2+}$. His-3 is highly conserved in mammals, except dogs and pig albumins [75]. They have His-3 substituted with Tyr-3, leading to higher suscpetibility of copper toxicity in these species [72]. The $\mathrm{Ni}^{2+}$ affinity to the NTS is comparatively lower, with a dissociation constant value of $2.5 \times 10^{-10} \mathrm{M}$. $\mathrm{Co}^{2+}$ ions also bind to the NTS and have a dissociation constant of $1 \times 10^{-4} \mathrm{M}$ [74]. The NTS has a highly flexible conformation as it is not observed even in the high-resolution crystal structures of albumin.

\subsection{The Cys-34 Metal-Binding Site}

The second metal-binding site is present at reduced Cys-34 residue [6,72]. It is the only cysteine residue within HSA that does not pair with another cysteine to form an intramolecular disulfide bond [45]. The disulfide bond patterns are highly conserved in all vertebrate albumins with 17 disulfide bridges and a single free thiol cysteine residue [45,47,76]. HSA, in its reduced form, has the free thiol of Cys-34. However, this amino acid residue tends to form a heterogenic disulfide bond with other cysteines, leading to protein dimerization [44]. Cys-34 is located in a cleft between helices 2 and 3 of subdomain IA, which results in limited accessibility and high specificity in metal ion interactions [44,72]. $\mathrm{Ag}^{+}, \mathrm{Au}^{+}, \mathrm{Hg}^{2+}, \mathrm{Pt}^{2+}$, and $\mathrm{Fe}^{2+}$ metal ions specifically bind to Cys-34 [72]. $\mathrm{Ag}^{+}$has a measured dissociation constant on $1 \times 10^{-5} \mathrm{M}$ for its binding to Cys-34 [77].

\subsection{The Multi-Metal Binding Sites $A$ and $B(M B S-A,-B)$}

The MBS-A is present at the interface of domains I and II [6]. The MBS-A and MBS-B are also known as primary and secondary cadmium binding sites as $\mathrm{Cd}^{2+}$ was the first metal ion associated with these sites in NMR studies [78,79]. Site-directed mutagenesis studies show that His-67 present in domain I is crucial for $\mathrm{Cd}^{2+}$ binding for MBS-A [79]. The dissociation constant for $\mathrm{Cd}^{2+}$ binding at MBS-A and -B is $5.0 \times 10^{-6} \mathrm{M}$ [79].

X-ray crystallographic studies of apo and metal bound HSA and site-directed mutagenesis analysis have identified Asn-99 present in domain I, His-247, and Asp-249 in domain II as primary residues that coordinate with $\mathrm{Zn}^{2+}$ in MBS-A $[79,80]$. The dissociation constant for $\mathrm{Zn}^{2+}$ binding is $2 \times 10^{-5} \mathrm{M}$ [80]. It is now well documented that $\mathrm{Zn}^{2+}$ ion binds primarily at MBS-A to induce cooperative allostery [72,80]. FA1, FA2, and FA7 binding sites surround the MBS-A, suggesting that the FA loading significantly influences the metal ion affinity to MBS-A [6,72]. The MBS-A additionally binds to $\mathrm{Cu}^{2+}$ and $\mathrm{Ni}^{2+}$. The multi-metal binding site B (MBS-B) is the fourth and final metal-binding site $[6,79,80]$. This site primarily associates with $\mathrm{Cd}^{2+}$ ions [72]. The amino acids involved in the $\mathrm{Cd}^{2+}$ binding at MBS-B are unknown. This site might have a higher degree of flexibility, resulting in multiple conformations; hence, it has not been characterized with confidence by X-ray crystallography or other structural methods. Recently, $\mathrm{Co}^{2+}$ ions were also shown to be associated with MSB-B [81].

The toxic effects of metals ions can be detrimental to cell growth, however, some metal ions are required for efficient cell growth as they serve as co-factors for several enzymes involved in critical biological pathways [11]. Albumin, with its ability to interact with various metal ions, can play a dual role in both scenarios. Some metal ions such as vanadium (bound to the drug binding site 1) and selenium (attached to disulfide bonds) are essential for cell growth under in vivo and in vitro conditions [82-84]. Albumin coordinates with these trace elements and ensures their transport for optimal cell growth and survival. 


\section{Antioxidant Features of HSA}

The antioxidant activity of HSA is primarily attributed to the redox properties of the four main metal-binding sites [85]. Free $\mathrm{Cu}^{+}, \mathrm{Fe}^{2+}$, and other metal ions react with oxygen to generate ROS [86]. Moreover, they can also interact with $\mathrm{H}_{2} \mathrm{O}_{2}$ to generate harmful hydroxyl radicals [86]. On the other hand, albumin binding to the metal ions limits the ability of these ions to participate in the ROS generation [85].

The industrial-scale eukaryotic cell cultures performed in bioreactors contain dissolved oxygen and free metals such as iron, copper, cobalt, and nickel, generating ROS that degrades the cell membranes [11,87]. The inclusion of BSA or HSA leads to lower ROS stress, enabling healthy cell cultures. On the other hand, the binding of albumins to these metals, especially copper, zinc, vanadium, and selenium, facilitates the uptake of these metals by cells, stimulating culture growth and considerably improving recombinant protein production in eukaryotic cells [11].

\section{Pyridoxal and Riboflavin Interactions}

Amino acids are the critical components of cell culture media. Any cell culture medium composition comprises essential amino acids that are required by the cells for efficient translation of the proteins ensuring optimal cell growth, survival, and cell division. Pyridoxal and its derivative pyridoxal $5^{\prime}$ phosphate (PLP) react with free amino acids, especially lysine and arginine, to form a Schiff base [88]. These Schiff bases are highly unstable. When exposed to metal ions, they lead to amino acid degradation prohibiting cell growth under in vitro culture conditions. The free pyridoxal moieties are sequestered by binding to albumin [89]. PLP forms a Schiff base with the Lys-190 of HSA [90]. The HSA stabilizes PLP by preventing its degradation [89,91]. It removes the free PLP contaminants from the cell culture media barring PLP-amino acid complex formation.

Riboflavin is another factor that can react with free amino acids to degrade them [92]. It acts as a photosensitizer and oxidizes free amino acids such as tryptophan that are present in the cell culture media. The photoproduct of the riboflavin-amino acid complex is known as lumichrome [92]. This lumichrome formation leads to rapid degradation of the riboflavinbound amino acids [92,93]. Albumin stabilizes the photoreactive riboflavin. It donates an electron to riboflavin, creating a reduced inactive adduct [94,95]. By doing so, albumin titrates free riboflavins in the cell culture media, eliminating amino acid degradation.

\section{Chemical Modifications of HSA}

Albumins undergo several post-translational modifications that influence the ligand binding and other activity of the proteins [96]. These chemical modifications are acetylation, glycosylation, glycation, nitrosylation, oxidation, carbonylation, phosphorylation, and chlorination [6]. Here, we only discuss essential modifications that influence albumin's function as an additive in cell culture. Albumin glycation occurs when the amino group of a basic residue forms a Schiff base with a sugar carbonyl group [97,98]. Arg410 and Lys 525 are glycation hotspots in HSA [98]. Upon glycation, albumin shows a significant change in protein conformation caused by a loss in secondary and tertiary structures [99]. Glycation triggers modification of critical residues such as His and Trp, as observed by the loss of intrinsic fluorescence of the protein $[100,101]$. These modifications also impair the antioxidant properties of albumin [6]. It has been shown that as little as one glycyl group attached to albumin can cause toxicity [6]. Thus, the albumin purification process from plasma or recombinant protein from heterologous sources should avoid albumin glycation.

The Cys34 is another chemical modification hotspot [102,103]. S-nitrosylation of Cys34 alters its metal-binding properties [96]. Cys34 oxidation attributes to the significant antioxidant activity of albumins [96]. Additionally, methionine residues also undergo oxidation to scavenge the reactive oxygen species [104]. Met87, Met123, Met329, Met446, and Met548 are primary residues that act as metal chelators to neutralize the ROS [56]. Together, Met and Cys residues account for $40-80 \%$ of the antioxidant activity of HSA $[56,85]$. 


\section{Ligand Interactions}

The ligand-binding sites are the primary basis of HSA-based cargo delivery $[9,105]$. High-resolution structures of HSA with therapeutic compounds alongside biochemical and biophysical studies have characterized three ligand binding sites located in the IIA, IIIA, and IB subdomains (Figure 1). The IIA and IIIA subdomain binding sites are commonly referred to as 'Sudlow sites' 1 and 2, respectively [68]. Carter et al. demonstrated the presence of the third major drug-binding region of HSA in the subdomain IB [106,107].

The drug-binding site 1 (Sudlow site 1) is present in subdomain IIA. The site is predominantly apolar, with a couple of groups of polar residues. One group of polar residues is present at the very bottom of the site and comprises residues Tyr150, His242, and Arg257 [9]. The second group is located at the opening of the binding pocket and contains residues Lys195, Lys199, Arg218, and Arg222 [9]. The abundance of basic residues defines the ligand-binding specificity of this site. The Sudlow site 1 accepts warfarin, phenylbutazone, amantadine, azapropazone, azidothymidine, indomethacin, iodipamide, oxyphenbutazone, $2^{\prime}$ indole sulfate, and $3^{\prime}$ diflunisal [9].

The subdomain IIIA harbors the drug-binding site 2 (Sudlow site 2) [9]. This ligandbinding pocket is predominantly hydrophobic, with characteristic electrostatic features. Polar residues present at one side of the binding pocket entrance [9]. Arg410, Ser489, and Lys414 are critical residues within this site that interact with associated ligands. Several drug molecules such as ibuprofen, digitoxin, benzodiazepine, halothane, propofol, and non-steroid anti-inflammatory drugs are shown to bind specifically to this drug site 2 [9].

A third drug binding site, identified in subdomain IB, has been shown to accommodate lidocaine, bilirubin, warfarin, myristic acid, naproxen, indomethacin, and heme iophenoxic acid [106]. This site offers more affinity towards endogenous ligands and heterocyclic compounds. Tyr138, Tyr161, Arg141, and Lys190 are the critical residues involved in ligand binding site [108].

The ligand-binding affinity of all these sites is affected by the conformational changes that occurred due to FA binding [6]. The FAs association with the albumin has shown to increase the binding affinity of ligands such as warfarin to the Sudlow site1 while decreasing the binding affinity of diazepam to the Sudlow site 2 [96]. The Sudlow sites 1 and 2, and third ligand binding site share the amino acid composition with the FA binding hotspots [6]. The FA7-binding site overlaps with Sudlow site 1, and the FA3and FA4-binding sites overlap with Sudlow site 2 [6]. Allosteric changes resulting in FA binding might affect the ligand interacting side chains of the amino acids lining the binding pocket $[6,57,58]$.

The HSA sequesters and transports free heme by interacting with the third drug binding site in the subdomain IB [6]. Heme under physiological conditions serves as a prosthetic group for heme-binding proteins essential for the growth and division of cells. Higher levels of heme can cause generation of ROS, resulting in oxidative stress [109]. Heme also causes the oxidation of high- and low-density lipoproteins [110]. HSA titrates the surplus heme and channels it into the heme degradation pathways, thus helping in cell survival [111]. Similarly, the HSA-bilirubin complex prevents cell death from bilirubin toxicity in culture conditions [112].

\section{Protein Interactions}

Various protein interactions facilitate albumin uptake from the extracellular environment to inside the cell. Specialized plasma membrane surface proteins are involved in these processes. These membrane proteins use clathrin-dependent or dynamin-dependent endocytosis processes. Some of the common membrane-bound albumin-binding proteins are glycoprotein 60 (gp60)/albondin, gp18, gp30, apolipoprotein B-100, IgG receptor FcRn large subunit p51, alpha-2-HS-glycoprotein, apolipoprotein A-I, fibronectin type III, alpha1-acid glycoprotein 1, antithrombin-III, fibrinogen alpha chain, vascular endothelial growth factor A, and SPARC protein (secreted protein, acidic, and rich in cysteine) $[7,113-116]$. More than $50 \%$ of albumin is absorbed from the blood capillarylumen by albondin in- 
teractions [117]. SPARC protein binds to albumin in a similar fashion to albondin and is shown to enhance drug-bound albumin accumulation within tumorous tissues [116]. The most studied albumin interaction is the FcRn-albumin complex. The FcRn binding site is present in the C-terminal of the domain III of albumin. FcRn binds to albumin in a $\mathrm{pH}$-dependent manner. Site-directed mutation studies show that three conserved histidine residues (H646, H510, and H535) on domain III of HSA play a critical role in FcRn binding. The FcRn regulates the half-life of the bound albumin to about three weeks by protecting albumin from intracellular degradation [118]. Recently, recombinant albumin variants with altered FcRn binding kinetics resulted in an extended albumin half-life [119-121]. These protein interactions facilitate albumin trafficking inside the cells in a culture environment. This results in the import of albumin-bound ligands such as metals and FAs essential for optimal cell growth and survival [11].

\section{Protective Role of Albumin against Physical Damage in Cell Culture}

Eukaryotic cells, especially mammalian cells, are susceptible to physical stress in a bioreactor environment [122-125]. Albumin protects the eukaryotic cell damage in sparged and airlift type bioreactors [126]. Evidence shows that minimal usage $(1 \mathrm{~g} / \mathrm{L})$ of albumin can significantly reduce cell lysis in mammalian cell cultures in pilot airlift bioreactors or bubble-free membrane aerated bioreactors [127]. Albumins are also used along with other additives such as anti-foaming agents and pluronic acid as a shear protectant for optimal results [128]. It is now widely believed that albumins might interfere with the cell culture's physiochemical properties to prevent physical cell damage [128]. It is, however, largely unclear how additives, especially proteins such as albumin, prevent acute lethal cell damage in a bioreactor environment $[129,130]$.

\section{Role of Albumins in Bioprocess Development}

Albumins have now wholly replaced the usage of serum and its derivatives in bioprocess development on an industrial scale. This is possible only with the availability of desirable quantities of highly purified recombinant albumins expressed and purified from heterologous hosts [11]. It have been shown to maintain cell stability in bioreactors for producing interleukin-2 and other therapeutic proteins [127]. Albumins are used in antibody production in hybridoma cell culture media [131]. Albumins support the growth of the immortal cell lines in the culture medium, working as a physical shear protectant $[11,132]$. HSA is also used in stem cell culture applications to promote the highly reproducible differentiation of human embryonic stem cells [133]. HSA also promotes growth of mouse embryo culture [134]. rHSA is highly desirable for these purposes as it meets stringent regulatory requirements for clinical applications [23]. Albumin is used for the development of serum-free media for fibroblast culture [135,136]. Not all albumin has the same efficacy in the cell culture media. The purity of the protein and the composition of albumin-associated ligands are the key factors that govern the protein's role as an additive in culture media $[11,137]$. The ligands associated with the purified proteins heavily depend on the protein source (serum or recombinant) and the purification process [138]. This is the main reason for batch-to-batch variation in the cell culture with albumin as an additive $[138,139]$. The addition of stabilizers, such as octanoic acid, with rHSA compositions has been shown to have profound adverse effects in specific cell culture systems [140]. Moreover, different post-translational modifications, including glycation and oxidation in HSA from recombinant or serum origins, produce significant batch-to-batch variability [141]. It is generally advised to stick with one vendor and albumin manufacturer while optimizing a cell culture process.

Albumins are substituted by other synthetic or natural alternatives in modern-day cell culture media [142]. Hydrolysates, especially plant protein hydrolysates, are successfully used to substitute albumins in embryo culture media [143]. Hyaluronic acid is also used to replace albumin in the human embryo transfer medium [144]. Polyvinyl alcohol combined with amino acids is used to substitute albumins in culture medium for 
mouse pre-implantation embryos. Another popular approach is the protein-free cell culture media [145]. Proprietary formulations such as MEM and RPMI-1640 are protein-free. Compared to albumin-containing media, protein-free media can promote superior cell growth, higher protein expression, and facilitate simpler downstream purification for many recombinant proteins [146]. However, these formulations are usually cell-line specific and need to be verified or optimized for any given culture.

\section{Conclusions}

The inherent properties of the human serum albumin make it highly desirable for biotechnological applications. It is commonly used in cell culture applications as a replacement for traditionally used serum. It is a crucial transporter of biologically active components essential for the growth and survival of eukaryotic cells. With overgrowing applications in hybridoma culture media, stem cell culture media, and tissue engineering media, albumins are becoming more relevant to modern-day bioprocess development. High-resolution structures of HSA have identified critical residues for ligand binding and transport, which are essential for the growth and development of cells. This information can now be exploited by the modern-day recombinant DNA technology to design specific HSA variants in array-based experiments to test custom ligand transport, enhanced metal binding, or potent ROS scavenging activities, both in vivo and in vitro, in a cost-effective manner.

Funding: This work was supported by NIH/NCI Comprehensive Cancer Center Support grant (5P30CA021765) to St. Jude Children's Research Hospital and by ALSAC. The authors views do not necessarily represent the official views of the funding agencies.

Conflicts of Interest: The authors declare no conflict of interest.

\section{References}

1. Kalra, H.; Adda, C.G.; Liem, M.; Ang, C.S.; Mechler, A.; Simpson, R.J.; Hulett, M.D.; Mathivanan, S. Comparative proteomics evaluation of plasma exosome isolation techniques and assessment of the stability of exosomes in normal human blood plasma. Proteomics 2013, 13, 3354-3364. [CrossRef]

2. El-Fakharany, E.M.; Abu-Serie, M.M.; Litus, E.A.; Permyakov, S.E.; Permyakov, E.A.; Uversky, V.N.; Redwan, E.M. The Use of Human, Bovine, and Camel Milk Albumins in Anticancer Complexes with Oleic Acid. Protein J. 2018, 37, 203-215. [CrossRef]

3. Abeyrathne, E.D.; Lee, H.Y.; Ahn, D.U. Egg white proteins and their potential use in food processing or as nutraceutical and pharmaceutical agents-A review. Poult. Sci. 2013, 92, 3292-3299. [CrossRef]

4. Zilic, S.; Barac, M.; Pesic, M.; Dodig, D.; Ignjatovic-Micic, D. Characterization of proteins from grain of different bread and durum wheat genotypes. Int. J. Mol. Sci. 2011, 12, 5878-5894. [CrossRef] [PubMed]

5. Peters, T. All About Albumin: Biochemistry, Genetics and Medical Application; Academic Press Limited: Cambridge, MA, USA, 1995.

6. Fanali, G.; di Masi, A.; Trezza, V.; Marino, M.; Fasano, M.; Ascenzi, P. Human serum albumin: From bench to bedside. Mol. Asp. Med. 2012, 33, 209-290. [CrossRef]

7. Merlot, A.M.; Kalinowski, D.S.; Richardson, D.R. Unraveling the mysteries of serum albumin-more than just a serum protein. Front. Physiol. 2014, 5, 299. [CrossRef] [PubMed]

8. Evans, T.W. Albumin as a drug-biological effects of albumin unrelated to oncotic pressure. Aliment. Pharmacol. Ther. 2002, 16 (Suppl. 5), 6-11. [CrossRef] [PubMed]

9. Ghuman, J.; Zunszain, P.A.; Petitpas, I.; Bhattacharya, A.A.; Otagiri, M.; Curry, S. Structural basis of the drug-binding specificity of human serum albumin. J. Mol. Biol. 2005, 353, 38-52. [CrossRef]

10. Lei, J.; Guan, B.; Li, B.; Duan, Z.; Chen, Y.; Li, H.; Jin, J. Expression, purification and characterization of recombinant human interleukin-2-serum albumin (rhil-2-hsa) fusion protein in pichia pastoris. Protein Expr. Purif. 2012, 84, 154-160. [CrossRef] [PubMed]

11. Francis, G.L. Albumin and mammalian cell culture: Implications for biotechnology applications. Cytotechnology 2010, 62, 1-16. [CrossRef]

12. Keenan, J.; Dooley, M.; Pearson, D.; Clynes, M. Recombinant Human Albumin in Cell Culture: Evaluation of Growth-Promoting Potential for NRK and SCC-9 Cells In Vitro. Cytotechnology 1997, 24, 243-252. [CrossRef] [PubMed]

13. Karimi, M.; Bahrami, S.; Ravari, S.B.; Zangabad, P.S.; Mirshekari, H.; Bozorgomid, M.; Shahreza, S.; Sori, M.; Hamblin, M.R. Albumin nanostructures as advanced drug delivery systems. Expert Opin. Drug Deliv. 2016, 13, 1609-1623. [CrossRef] [PubMed]

14. He, Y.; Ning, T.; Xie, T.; Qiu, Q.; Zhang, L.; Sun, Y.; Jiang, D.; Fu, K.; Yin, F.; Zhang, W.; et al. Large-scale production of functional human serum albumin from transgenic rice seeds. Proc. Natl. Acad. Sci. USA 2011, 108, 19078-19083. [CrossRef] [PubMed] 
15. Zhu, W.; Gong, G.; Pan, J.; Han, S.; Zhang, W.; Hu, Y.; Xie, L. High level expression and purification of recombinant human serum albumin in Pichia pastoris. Protein Expr. Purif. 2018, 147, 61-68. [CrossRef]

16. Sun, Q.Y.; Ding, L.W.; Lomonossoff, G.P.; Sun, Y.B.; Luo, M.; Li, C.Q.; Jiang, L.; Xu, Z.F. Improved expression and purification of recombinant human serum albumin from transgenic tobacco suspension culture. J. Biotechnol. 2011, 155, 164-172. [CrossRef]

17. Chen, Z.; He, Y.; Shi, B.; Yang, D. Human serum albumin from recombinant DNA technology: Challenges and strategies. Biochim. Biophys. Acta Gen. Subj. 2013, 1830, 5515-5525. [CrossRef] [PubMed]

18. Sharma, A.; Chaudhuri, T.K. Revisiting Escherichia coli as microbial factory for enhanced production of human serum albumin. Microb. Cell Factories 2017, 16, 173. [CrossRef] [PubMed]

19. Nguyen, M.T.; Heo, Y.; Do, B.H.; Baek, S.; Kim, C.J.; Jang, Y.J.; Lee, W.; Choe, H. Bacterial overexpression and purification of soluble recombinant human serum albumin using maltose-binding protein and protein disulphide isomerase. Protein Expr. Purif. 2020, 167, 105530. [CrossRef] [PubMed]

20. Sleep, D.; Belfield, G.P.; Goodey, A.R. The secretion of human serum albumin from the yeast Saccharomyces cerevisiae using five different leader sequences. Biotechnology 1990, 8, 42-46. [CrossRef] [PubMed]

21. Fleer, R.; Yeh, P.; Amellal, N.; Maury, I.; Fournier, A.; Bacchetta, F.; Baduel, P.; Jung, G.; L'Hote, H.; Becquart, J.; et al. Stable multicopy vectors for high-level secretion of recombinant human serum albumin by Kluyveromyces yeasts. Biotechnology 1991, 9 , 968-975. [CrossRef]

22. Barash, I.; Faerman, A.; Baruch, A.; Nathan, M.; Hurwitz, D.R.; Shani, M. Synthesis and secretion of human serum albumin by mammary gland explants of virgin and lactating transgenic mice. Transgenic Res. 1993, 2, 266-276. [CrossRef]

23. Chuang, V.T.; Otagiri, M. Recombinant human serum albumin. Drugs Today (Barc) 2007, 43, 547-561. [CrossRef] [PubMed]

24. Larsen, M.T.; Kuhlmann, M.; Hvam, M.L.; Howard, K.A. Albumin-based drug delivery: Harnessing nature to cure disease. Mol. Cell Ther. 2016, 4, 3. [CrossRef]

25. Zhou, G.; Jin, X.; Zhu, P.; Yao, J.U.; Zhang, Y.; Teng, L.; Lee, R.J.; Zhang, X.; Hong, W. Human serum albumin nanoparticles as a novel delivery system for cabazitaxel. Anticancer Res. 2016, 36, 1649-1656.

26. An, F.F.; Zhang, X.H. Strategies for preparing albumin-based nanoparticles for multifunctional bioimaging and drug delivery. Theranostics 2017, 7, 3667-3689. [CrossRef]

27. Liu, Z; Chen, X. Simple bioconjugate chemistry serves great clinical advances: Albumin as a versatile platform for diagnosis and precision therapy. Chem. Soc. Rev. 2016, 45, 1432-1456. [CrossRef] [PubMed]

28. Tao, C.; Chuah, Y.J.; Xu, C.; Wang, D.A. Albumin conjugates and assemblies as versatile bio-functional additives and carriers for biomedical applications. J. Mater. Chem. B 2019, 7, 357-367. [CrossRef] [PubMed]

29. Merten, O.W. Development of serum-free media for cell growth and production of viruses/viral vaccines-safety issues of animal products used in serum-free media. Dev. Biol. 2002, 111, 233-257.

30. Keenan, J.; Pearson, D.; Clynes, M. The role of recombinant proteins in the development of serum-free media. Cytotechnology 2006, 50, 49-56. [CrossRef] [PubMed]

31. Keenan, J.; Doherty, G.; Clynes, M. Separation of growth-stimulating activity of BSA fraction V from the bulk of albumin using Heparin Sepharose Chromatography. Cytotechnology 1995, 19, 63-72. [CrossRef]

32. Curling, J.M.; Berglof, J.; Lindquist, L.O.; Eriksson, S. A chromatographic procedure for the purification of human plasma albumin. Vox Sang. 1977, 33, 97-107. [CrossRef] [PubMed]

33. Ohtani, W.; Ohda, T.; Sumi, A.; Kobayashi, K.; Ohmura, T. Analysis of Pichia pastoris components in recombinant human serum albumin by immunological assays and by HPLC with pulsed amperometric detection. Anal. Chem. 1998, 70, 425-429. [CrossRef]

34. Mallem, M.; Warburton, S.; Li, F.; Shandil, I.; Nylen, A.; Kim, S.; Jiang, Y.; Meehl, M.; d'Anjou, M.; Stadheim, T.A.; et al. Maximizing recombinant human serum albumin production in a Mut(s) pichia pastoris strain. Biotechnol. Prog. 2014, 30, 1488-1496. [CrossRef] [PubMed]

35. Taghizadeh, S.M.; Ebrahiminezhad, A.; Ghoshoon, M.B.; Dehshahri, A.; Berenjian, A.; Ghasemi, Y. Magnetic immobilization of Pichia pastoris cells for the production of recombinant human serum albumin. Nanomaterials 2020, 10, 111. [CrossRef]

36. Li, S.; Li, L.; Chen, Z.; Xue, G.; Jiang, L.; Zheng, K.; Chen, J.; Li, R.; Yuan, C.; Huang, M. A novel purification procedure for recombinant human serum albumin expressed in pichia pastoris. Protein Expr. Purif. 2018, 149, 37-42. [CrossRef]

37. Zhu, R.Y.; Xin, X.; Dai, H.Y.; Li, Q.; Lei, J.Y.; Chen, Y.; Jin, J. Expression and purification of recombinant human serum albumin fusion protein with VEGF165b in Pichia pastoris. Protein Expr. Purif. 2012, 85, 32-37. [CrossRef] [PubMed]

38. Liu, Y.K.; Li, Y.T.; Lu, C.F.; Huang, L.F. Enhancement of recombinant human serum albumin in transgenic rice cell culture system by cultivation strategy. New Biotechnol. 2015, 32, 328-334. [CrossRef]

39. Pang, J.; Zhou, J.; Yang, D. Knock-in at GluA1 locus improves recombinant human serum albumin expression in rice grain. J. Biotechnol. 2020, 321, 87-95. [CrossRef]

40. Saunders, C.W.; Schmidt, B.J.; Mallonee, R.L.; Guyer, M.S. Secretion of human serum albumin from Bacillus subtilis. J. Bacteriol. 1987, 169, 2917-2925. [CrossRef]

41. Sharma, A.; Chaudhuri, T.K. Physicochemical characterization of E. coli-derived human serum albumin and its comparison with the human plasma counterpart reveals it as a promising biosimilar. J. Biotechnol. 2018, 274, 1-8. [CrossRef]

42. Strauss, A.W.; Bennett, C.A.; Donohue, A.M.; Rodkey, J.A.; Boime, I.; Alberts, A.W. Conversion of rat pre-proalbumin to proalbumin in vitro by ascites membranes. Demonstration by NH2-TERMINAL SEQUENCE ANALYSIS. J. Biol. Chem. 1978, 253, 6270-6274. [CrossRef] 
43. Brennan, S.O.; Carrell, R.W. A circulating variant of human proalbumin. Nature 1978, 274, 908-909. [CrossRef]

44. He, X.M.; Carter, D.C. Atomic structure and chemistry of human serum albumin. Nature 1992, 358, 209-215. [CrossRef] [PubMed]

45. Sugio, S.; Kashima, A.; Mochizuki, S.; Noda, M.; Kobayashi, K. Crystal structure of human serum albumin at 2.5 A resolution. Protein Eng. 1999, 12, 439-446. [CrossRef]

46. Murayama, K.; Tomida, M. Heat-induced secondary structure and conformation change of bovine serum albumin investigated by Fourier transform infrared spectroscopy. Biochemistry 2004, 43, 11526-11532. [CrossRef]

47. Bujacz, A. Structures of bovine, equine and leporine serum albumin. Acta Crystallogr. Sect. D Biol. Crystallogr. 2012, 68, 1278-1289. [CrossRef]

48. Majorek, K.A.; Porebski, P.J.; Dayal, A.; Zimmerman, M.D.; Jablonska, K.; Stewart, A.J.; Chruszcz, M.; Minor, W. Structural and immunologic characterization of bovine, horse, and rabbit serum albumins. Mol. Immunol. 2012, 52, 174-182. [CrossRef] [PubMed]

49. Ketrat, S.; Japrung, D.; Pongprayoon, P. Exploring how structural and dynamic properties of bovine and canine serum albumins differ from human serum albumin. J. Mol. Graph. Model. 2020, 98, 107601. [CrossRef] [PubMed]

50. Huang, B.X.; Kim, H.Y.; Dass, C. Probing three-dimensional structure of bovine serum albumin by chemical cross-linking and mass spectrometry. J. Am. Soc. Mass Spectrom. 2004, 15, 1237-1247. [CrossRef]

51. Paris, G.; Kraszewski, S.; Ramseyer, C.; Enescu, M. About the structural role of disulfide bridges in serum albumins: Evidence from protein simulated unfolding. Biopolymers 2012, 97, 889-898. [CrossRef] [PubMed]

52. Chubarov, A.; Spitsyna, A.; Krumkacheva, O.; Mitin, D.; Suvorov, D.; Tormyshev, V.; Fedin, M.; Bowman, M.K.; Bagryanskaya, E. Reversible dimerization of human serum albumin. Molecules 2021, 26, 108. [CrossRef] [PubMed]

53. Steglich, M.; Lombide, R.; Lopez, I.; Portela, M.; Flo, M.; Marin, M.; Alvarez, B.; Turell, L. Expression, purification and initial characterization of human serum albumin domain I and its cysteine 34. PLoS ONE 2020, 15, e0240580. [CrossRef]

54. Roche, M.; Rondeau, P.; Singh, N.R.; Tarnus, E.; Bourdon, E. The antioxidant properties of serum albumin. FEBS Lett. 2008, 582, 1783-1787. [CrossRef]

55. Oettl, K.; Stauber, R.E. Physiological and pathological changes in the redox state of human serum albumin critically influence its binding properties. Br. J. Pharmacol. 2007, 151, 580-590. [CrossRef] [PubMed]

56. Bourdon, E.; Loreau, N.; Lagrost, L.; Blache, D. Differential effects of cysteine and methionine residues in the antioxidant activity of human serum albumin. Free Radic. Res. 2005, 39, 15-20. [CrossRef]

57. van der Vusse, G.J. Albumin as fatty acid transporter. Drug Metab. Pharmacokinet. 2009, 24, 300-307. [CrossRef] [PubMed]

58. Curry, S.; Mandelkow, H.; Brick, P.; Franks, N. Crystal structure of human serum albumin complexed with fatty acid reveals an asymmetric distribution of binding sites. Nat. Struct. Biol. 1998, 5, 827-835. [CrossRef]

59. Brown, N.A.; Wilson, A.G.; Bridges, J.W. Chain length dependency of fatty acid and carbamate binding to serum albumin. Biochem. Pharmacol. 1982, 31, 4019-4029. [CrossRef]

60. Fanali, G.; Fesce, R.; Agrati, C.; Ascenzi, P.; Fasano, M. Allosteric modulation of myristate and Mn(III)heme binding to human serum albumin. Optical and NMR spectroscopy characterization. FEBS J. 2005, 272, 4672-4683. [CrossRef]

61. Huang, B.X.; Dass, C.; Kim, H.Y. Probing conformational changes of human serum albumin due to unsaturated fatty acid binding by chemical cross-linking and mass spectrometry. Biochem. J. 2005, 387, 695-702. [CrossRef]

62. Bos, O.J.; Labro, J.F.; Fischer, M.J.; Wilting, J.; Janssen, L.H. The molecular mechanism of the neutral-to-base transition of human serum albumin: Acid/Base titration and proton nuclear magnetic resonance studies on a large peptic and a large tryptic fragment of albumin. J. Biol. Chem. 1989, 264, 953-959. [CrossRef]

63. Dockal, M.; Carter, D.C.; Ruker, F. Conformational transitions of the three recombinant domains of human serum albumin depending on pH. J. Biol. Chem. 2000, 275, 3042-3050. [CrossRef]

64. Barbosa, L.R.; Ortore, M.G.; Spinozzi, F.; Mariani, P.; Bernstorff, S.; Itri, R. The importance of protein-protein interactions on the $\mathrm{pH}$-induced conformational changes of bovine serum albumin: A small-angle X-ray scattering study. Biophys. J. 2010, 98, 147-157. [CrossRef]

65. Simard, J.R.; Zunszain, P.A.; Ha, C.E.; Yang, J.S.; Bhagavan, N.V.; Petitpas, I.; Curry, S.; Hamilton, J.A. Locating high-affinity fatty acid-binding sites on albumin by x-ray crystallography and NMR spectroscopy. Proc. Natl. Acad. Sci. USA 2005, 102, 17958-17963. [CrossRef] [PubMed]

66. Simard, J.R.; Zunszain, P.A.; Hamilton, J.A.; Curry, S. Location of high and low affinity fatty acid binding sites on human serum albumin revealed by NMR drug-competition analysis. J. Mol. Biol. 2006, 361, 336-351. [CrossRef]

67. Bhattacharya, A.A.; Grune, T.; Curry, S. Crystallographic analysis reveals common modes of binding of medium and long-chain fatty acids to human serum albumin. J. Mol. Biol. 2000, 303, 721-732. [CrossRef] [PubMed]

68. Sudlow, G.; Birkett, D.J.; Wade, D.N. The characterization of two specific drug binding sites on human serum albumin. Mol. Pharmacol. 1975, 11, 824-832.

69. Krzywoszynska, K.; Witkowska, D.; Swiatek-Kozlowska, J.; Szebesczyk, A.; Kozlowski, H. General aspects of metal ions as signaling agents in health and disease. Biomolecules 2020, 10, 1417. [CrossRef]

70. Al-Harthi, S.; Lachowicz, J.I.; Nowakowski, M.E.; Jaremko, M.; Jaremko, L. Towards the functional high-resolution coordination chemistry of blood plasma human serum albumin. J. Inorg. Biochem. 2019, 198, 110716. [CrossRef]

71. Angele-Martinez, C.; Nguyen, K.V.; Ameer, F.S.; Anker, J.N.; Brumaghim, J.L. Reactive oxygen species generation by copper(II) oxide nanoparticles determined by DNA damage assays and EPR spectroscopy. Nanotoxicology 2017, 11, 278-288. [CrossRef] 
72. Bal, W.; Sokolowska, M.; Kurowska, E.; Faller, P. Binding of transition metal ions to albumin: Sites, affinities and rates. Biochim. Biophys. Acta 2013, 1830, 5444-5455. [CrossRef] [PubMed]

73. Sadler, P.J.; Tucker, A.; Viles, J.H. Involvement of a lysine residue in the $\mathrm{N}$-terminal $\mathrm{Ni}^{2+}$ and $\mathrm{Cu}^{2+}$ binding site of serum albumins. Comparison with $\mathrm{Co}^{2+}, \mathrm{Cd}^{2+}$ and $\mathrm{Al}^{3+}$. Eur. J. Biochem. 1994, 220, 193-200. [CrossRef]

74. Masuoka, J.; Hegenauer, J.; Van Dyke, B.R.; Saltman, P. Intrinsic stoichiometric equilibrium constants for the binding of zinc(ii) and copper(II) to the high affinity site of serum albumin. J. Biol. Chem. 1993, 268, 21533-21537. [CrossRef]

75. Glennon, J.D.; Sarkar, B. The non-specificity of dog serum albumin and the N-terminal model peptide glycylglycyl-L-tyrosine $\mathrm{N}$-methylamide for nickel is due to the lack of histidine in the third position. Biochem. J. 1982, 203, 25-31. [CrossRef]

76. Bujacz, A.; Talaj, J.A.; Zielinski, K.; Pietrzyk-Brzezinska, A.J.; Neumann, P. Crystal structures of serum albumins from domesticated ruminants and their complexes with 3,5-diiodosalicylic acid. Acta Crystallogr. Sect. D Struct. Biol. 2017, 73, 896-909. [CrossRef] [PubMed]

77. Shen, X.C.; Liang, H.; Guo, J.H.; Song, C.; He, X.W.; Yuan, Y.Z. Studies on the interaction between $\mathrm{Ag}^{+}$and human serum albumin. J. Inorg. Biochem. 2003, 95, 124-130. [CrossRef]

78. Sadler, P.J.; Viles, J.H. $1 \mathrm{H}$ and (113)Cd NMR investigations of $\mathrm{Cd}^{2+}$ and $\mathrm{Zn}^{2+}$ binding sites on serum albumin: Competition with $\mathrm{Ca}^{2+}, \mathrm{Ni}^{2+}, \mathrm{Cu}^{2+}$, and $\mathrm{Zn}^{2+}$. Inorg. Chem. 1996, 35, 4490-4496. [CrossRef] [PubMed]

79. Stewart, A.J.; Blindauer, C.A.; Berezenko, S.; Sleep, D.; Sadler, P.J. Interdomain zinc site on human albumin. Proc. Natl. Acad. Sci. USA 2003, 100, 3701-3706. [CrossRef] [PubMed]

80. Lu, J.; Stewart, A.J.; Sadler, P.J.; Pinheiro, T.J.; Blindauer, C.A. Albumin as a zinc carrier: Properties of its high-affinity zinc-binding site. Biochem. Soc. Trans. 2008, 36, 1317-1321. [CrossRef]

81. Mothes, E.; Faller, P. Evidence that the principal CoII-binding site in human serum albumin is not at the N-terminus: Implication on the albumin cobalt binding test for detecting myocardial ischemia. Biochemistry 2007, 46, 2267-2274. [CrossRef]

82. Makinen, M.W.; Brady, M.J. Structural origins of the insulin-mimetic activity of bis(acetylacetonato)oxovanadium(IV). J. Biol. Chem. 2002, 277, 12215-12220. [CrossRef]

83. Liboiron, B.D.; Thompson, K.H.; Hanson, G.R.; Lam, E.; Aebischer, N.; Orvig, C. New insights into the interactions of serum proteins with bis(maltolato)oxovanadium(IV): Transport and biotransformation of insulin-enhancing vanadium pharmaceuticals. J. Am. Chem. Soc. 2005, 127, 5104-5115. [CrossRef]

84. Haratake, M.; Hongoh, M.; Miyauchi, M.; Hirakawa, R.; Ono, M.; Nakayama, M. Albumin-mediated selenium transfer by a selenotrisulfide relay mechanism. Inorg. Chem. 2008, 47, 6273-6280. [CrossRef] [PubMed]

85. Taverna, M.; Marie, A.L.; Mira, J.P.; Guidet, B. Specific antioxidant properties of human serum albumin. Ann. Intensive Care 2013, 3, 4. [CrossRef] [PubMed]

86. Phaniendra, A.; Jestadi, D.B.; Periyasamy, L. Free radicals: Properties, sources, targets, and their implication in various diseases. Indian J. Clin. Biochem. 2015, 30, 11-26. [CrossRef]

87. Quinlan, G.J.; Martin, G.S.; Evans, T.W. Albumin: Biochemical properties and therapeutic potential. Hepatology 2005, 41, 1211-1219. [CrossRef]

88. Liang, J.; Han, Q.; Tan, Y.; Ding, H.; Li, J. Current advances on structure-function relationships of pyridoxal 5'-phosphatedependent enzymes. Front. Mol. Biosci. 2019, 6, 4. [CrossRef] [PubMed]

89. Fonda, M.L.; Trauss, C.; Guempel, U.M. The binding of pyridoxal 5'-phosphate to human serum albumin. Arch. Biochem. Biophys. 1991, 288, 79-86. [CrossRef]

90. Bohney, J.P.; Fonda, M.L.; Feldhoff, R.C. Identification of Lys190 as the primary binding site for pyridoxal 5'-phosphate in human serum albumin. FEBS Lett. 1992, 298, 266-268. [CrossRef]

91. Hilak, M.C.; Harmsen, B.J.; Joordens, J.J.; Van Os, G.A. Binding of pyridoxal 5'-phosphate to bovine serum albumin and albumin fragments obtained after proteolytic hydrolysis. Localization and nature of the primary plp binding site. Int. J. Pept. Protein Res. 1975, 7, 411-416. [CrossRef] [PubMed]

92. Remucal, C.K.; McNeill, K. Photosensitized amino acid degradation in the presence of riboflavin and its derivatives. Environ. Sci. Technol. 2011, 45, 5230-5237. [CrossRef]

93. Huang, R.; Kim, H.J.; Min, D.B. Photosensitizing effect of riboflavin, lumiflavin, and lumichrome on the generation of volatiles in soy milk. J. Agric. Food Chem. 2006, 54, 2359-2364. [CrossRef] [PubMed]

94. Innis, W.S.; McCormick, D.B.; Merrill, A.H., Jr. Variations in riboflavin binding by human plasma: Identification of immunoglobulins as the major proteins responsible. Biochem. Med. 1985, 34, 151-165. [CrossRef]

95. Jusko, W.J.; Levy, G. Plasma protein binding of riboflavin and riboflavin-5'-phosphate in man. J. Pharm. Sci. 1969, 58, 58-62. [CrossRef] [PubMed]

96. Lee, P.; Wu, X. Modifications of human serum albumin and their binding effect. Curr. Pharm. Des. 2015, 21, 1862-1865. [CrossRef] [PubMed]

97. Ahmed, N.; Dobler, D.; Dean, M.; Thornalley, P.J. Peptide mapping identifies hotspot site of modification in human serum albumin by methylglyoxal involved in ligand binding and esterase activity. J. Biol. Chem. 2005, 280, 5724-5732. [CrossRef]

98. Otagiri, M.; Chuang, V.T. Pharmaceutically important pre- and posttranslational modifications on human serum albumin. Biol. Pharm. Bull. 2009, 32, 527-534. [CrossRef]

99. Coussons, P.J.; Jacoby, J.; McKay, A.; Kelly, S.M.; Price, N.C.; Hunt, J.V. Glucose modification of human serum albumin: A structural study. Free Radic. Biol. Med. 1997, 22, 1217-1227. [CrossRef] 
100. Ahmed, N.; Thornalley, P.J. Chromatographic assay of glycation adducts in human serum albumin glycated in vitro by derivatization with 6-aminoquinolyl-N-hydroxysuccinimidyl-carbamate and intrinsic fluorescence. Biochem. J. 2002, 364, 15-24. [CrossRef]

101. Iwao, Y.; Anraku, M.; Hiraike, M.; Kawai, K.; Nakajou, K.; Kai, T.; Suenaga, A.; Otagiri, M. The structural and pharmacokinetic properties of oxidized human serum albumin, advanced oxidation protein products (AOPP). Drug Metab. Pharmacokinet. 2006, 21, 140-146. [CrossRef]

102. Bertucci, C.; Nanni, B.; Salvadori, P. Reversible binding of ethacrynic acid to human serum albumin: Difference circular dichroism study. Chirality 1999, 11, 33-38. [CrossRef]

103. Stewart, A.J.; Blindauer, C.A.; Berezenko, S.; Sleep, D.; Tooth, D.; Sadler, P.J. Role of Tyr84 in controlling the reactivity of Cys34 of human albumin. FEBS J. 2005, 272, 353-362. [CrossRef]

104. Luo, S.; Levine, R.L. Methionine in proteins defends against oxidative stress. FASEB J. 2009, 23, 464-472. [CrossRef]

105. Carter, D.C.; Ho, J.X. Structure of serum albumin. Adv. Protein Chem. 1994, 45, 153-203. [CrossRef]

106. Zsila, F. Subdomain IB is the third major drug binding region of human serum albumin: Toward the three-sites model. Mol. Pharm. 2013, 10, 1668-1682. [CrossRef] [PubMed]

107. Carter, D.C. Crystallographic Survey of Albumin Drug Interaction and Applications in Cancer Chemotherapy. In Burger's Drug Design and Development, 7th ed.; John Wiley \& Sons: Hoboken, NJ, USA, 2010; pp. 437-468.

108. Ascenzi, P.; di Masi, A.; Fanali, G.; Fasano, M. Heme-based catalytic properties of human serum albumin. Cell Death Discov. 2015, 1, 15025. [CrossRef]

109. Dutra, F.F.; Bozza, M.T. Heme on innate immunity and inflammation. Front. Pharmacol. 2014, 5, 115. [CrossRef]

110. Balla, G.; Jacob, H.S.; Eaton, J.W.; Belcher, J.D.; Vercellotti, G.M. Hemin: A possible physiological mediator of low density lipoprotein oxidation and endothelial injury. Arterioscler. Thromb. 1991, 11, 1700-1711. [CrossRef] [PubMed]

111. Kamal, J.K.; Behere, D.V. Binding of heme to human serum albumin: Steady-state fluorescence, circular dichroism and optical difference spectroscopic studies. Indian J. Biochem. Biophys. 2005, 42, 7-12. [PubMed]

112. Hosainzadeh, A.; Gharanfoli, M.; Saberi, M.; Chamani, J. Probing the interaction of human serum albumin with bilirubin in the presence of aspirin by multi-spectroscopic, molecular modeling and zeta potential techniques: Insight on binary and ternary systems. J. Biomol. Struct. Dyn. 2012, 29, 1013-1050. [CrossRef]

113. Schnitzer, J.E.; Carley, W.W.; Palade, G.E. Albumin interacts specifically with a 60-kDa microvascular endothelial glycoprotein. Proc. Natl. Acad. Sci. USA 1988, 85, 6773-6777. [CrossRef]

114. Ghinea, N.; Fixman, A.; Alexandru, D.; Popov, D.; Hasu, M.; Ghitescu, L.; Eskenasy, M.; Simionescu, M.; Simionescu, N. Identification of albumin-binding proteins in capillary endothelial cells. J. Cell Biol. 1988, 107, 231-239. [CrossRef]

115. Roopenian, D.C.; Akilesh, S. FcRn: The neonatal Fc receptor comes of age. Nat. Rev. Immunol. 2007, 7, 715-725. [CrossRef]

116. Schnitzer, J.E.; Oh, P. Antibodies to SPARC Inhibit albumin binding to SPARC, gp60, and microvascular endothelium. Am. J. Physiol. 1992, 263, H1872-H1879. [CrossRef] [PubMed]

117. Schnitzer, J.E. Update on the cellular and molecular basis of capillary permeability. Trends Cardiovasc. Med. 1993, 3, 124-130. [CrossRef]

118. Nilsen, J.; Trabjerg, E.; Grevys, A.; Azevedo, C.; Brennan, S.O.; Stensland, M.; Wilson, J.; Sand, K.M.K.; Bern, M.; Dalhus, B.; et al. An intact C-terminal end of albumin is required for its long half-life in humans. Commun. Biol. 2020, 3, 181. [CrossRef]

119. Chaudhury, C.; Mehnaz, S.; Robinson, J.M.; Hayton, W.L.; Pearl, D.K.; Roopenian, D.C.; Anderson, C.L. The major histocompatibility complex-related Fc receptor for IgG (FcRn) binds albumin and prolongs its lifespan. J. Exp. Med. 2003, 197, 315-322. [CrossRef]

120. Kim, J.; Hayton, W.L.; Robinson, J.M.; Anderson, C.L. Kinetics of FcRn-mediated recycling of IgG and albumin in human: Pathophysiology and therapeutic implications using a simplified mechanism-based model. Clin. Immunol. 2007, 122, 146-155. [CrossRef]

121. Anderson, C.L.; Chaudhury, C.; Kim, J.; Bronson, C.L.; Wani, M.A.; Mohanty, S. Perspective-FcRn transports albumin: Relevance to immunology and medicine. Trends Immunol. 2006, 27, 343-348. [CrossRef] [PubMed]

122. Al-Rubeai, M.; Singh, R.P.; Goldman, M.H.; Emery, A.N. Death mechanisms of animal cells in conditions of intensive agitation. Biotechnol. Bioeng. 1995, 45, 463-472. [CrossRef]

123. Ma, N.; Koelling, K.W.; Chalmers, J.J. Fabrication and use of a transient contractional flow device to quantify the sensitivity of mammalian and insect cells to hydrodynamic forces. Biotechnol. Bioeng. 2002, 80, 428-437. [CrossRef]

124. Mollet, M.; Godoy-Silva, R.; Berdugo, C.; Chalmers, J.J. Acute hydrodynamic forces and apoptosis: A complex question. Biotechnol. Bioeng. 2007, 98, 772-788. [CrossRef]

125. Chisti, Y. Hydrodynamic damage to animal cells. Crit. Rev. Biotechnol. 2001, 21, 67-110. [CrossRef]

126. Chisti, Y. Animal-cell damage in sparged bioreactors. Trends Biotechnol. 2000, 18, 420-432. [CrossRef]

127. Hesse, F.; Ebel, M.; Konisch, N.; Sterlinski, R.; Kessler, W.; Wagner, R. Comparison of a production process in a membrane-aerated stirred tank and up to 1000-L airlift bioreactors using BHK-21 cells and chemically defined protein-free medium. Biotechnol. Prog. 2003, 19, 833-843. [CrossRef] [PubMed]

128. Kunas, K.T.; Papoutsakis, E.T. Damage mechanisms of suspended animal cells in agitated bioreactors with and without bubble entrainment. Biotechnol. Bioeng. 2009, 102, 980-987. [CrossRef]

129. Kunas, K.T.; Papoutsakis, E.T. Damage mechanisms of suspended animal cells in agitated bioreactors with and without bubble entrainment. Biotechnol. Bioeng. 1990, 36, 476-483. [CrossRef] [PubMed] 
130. Smith, C.G.; Greenfield, P.F. Mechanical agitation of hybridoma suspension cultures: Metabolic effects of serum, pluronic F68, and albumin supplements. Biotechnol. Bioeng. 1992, 40, 1045-1055. [CrossRef]

131. Glassy, M.C.; Tharakan, J.P.; Chau, P.C. Serum-free media in hybridoma culture and monoclonal antibody production. Biotechnol. Bioeng. 1988, 32, 1015-1028. [CrossRef]

132. Stadlmann, J.; Pabst, M.; Kolarich, D.; Kunert, R.; Altmann, F. Analysis of immunoglobulin glycosylation by LC-ESI-MS of glycopeptides and oligosaccharides. Proteomics 2008, 8, 2858-2871. [CrossRef]

133. Desai, N.; Rambhia, P.; Gishto, A. Human embryonic stem cell cultivation: Historical perspective and evolution of xeno-free culture systems. Reprod. Biol. Endocrinol. 2015, 13, 9. [CrossRef]

134. Otsuki, J.; Nagai, Y.; Matsuyama, Y.; Terada, T.; Era, S. The redox state of recombinant human serum albumin and its optimal concentration for mouse embryo culture. Syst. Biol. Reprod. Med. 2013, 59, 48-52. [CrossRef]

135. Yamazoe, H.; Uemura, T.; Tanabe, T. Facile cell patterning on an albumin-coated surface. Langmuir 2008, 24, 8402-8404. [CrossRef]

136. Yamazoe, H.; Tanabe, T. Preparation of water-insoluble albumin film possessing nonadherent surface for cells and ligand binding ability. J. Biomed. Mater. Res. A 2008, 86, 228-234. [CrossRef]

137. Lang, B.E.; Cole, K.D. Unfolding properties of recombinant human serum albumin products are due to bioprocessing steps. Biotechnol. Prog. 2015, 31, 62-69. [CrossRef] [PubMed]

138. Frahm, G.E.; Smith, D.G.; Kane, A.; Lorbetskie, B.; Cyr, T.D.; Girard, M.; Johnston, M.J. Determination of supplier-to-supplier and lot-to-lot variability in glycation of recombinant human serum albumin expressed in oryza sativa. PLoS ONE 2014, 9, e109893. [CrossRef] [PubMed]

139. Raoufinia, R.; Mota, A.; Keyhanvar, N.; Safari, F.; Shamekhi, S.; Abdolalizadeh, J. Overview of albumin and its purification methods. Adv. Pharm. Bull. 2016, 6, 495-507. [CrossRef] [PubMed]

140. Bar-Or, D.; Bar-Or, R.; Rael, L.T.; Gardner, D.K.; Slone, D.S.; Craun, M.L. Heterogeneity and oxidation status of commercial human albumin preparations in clinical use. Crit. Care Med. 2005, 33, 1638-1641. [CrossRef]

141. Miyamura, S.; Imafuku, T.; Anraku, M.; Taguchi, K.; Yamasaki, K.; Tominaga, Y.; Maeda, H.; Ishima, Y.; Watanabe, H.; Otagiri, M.; et al. Comparison of posttranslational modification and the functional impairment of human serum albumin in commercial preparations. J. Pharm. Sci. 2016, 105, 1043-1049. [CrossRef]

142. Yao, T.; Asayama, Y. Animal-cell culture media: History, characteristics, and current issues. Reprod. Med. Biol. 2017, 16, 99-117. [CrossRef]

143. George, F.; Kerschen, D.; Van Nuffel, A.; Rees, J.F.; Donnay, I. Plant protein hydrolysates (plant peptones) as substitutes for animal proteins in embryo culture medium. Reprod. Fertil. Dev. 2009, 21, 587-598. [CrossRef]

144. Simon, A.; Safran, A.; Revel, A.; Aizenman, E.; Reubinoff, B.; Porat-Katz, A.; Lewin, A.; Laufer, N. Hyaluronic acid can successfully replace albumin as the sole macromolecule in a human embryo transfer medium. Fertil. Steril. 2003, 79, 1434-1438. [CrossRef]

145. Biggers, J.D.; Summers, M.C.; McGinnis, L.K. Polyvinyl alcohol and amino acids as substitutes for bovine serum albumin in culture media for mouse preimplantation embryos. Hum. Reprod. Update 1997, 3, 125-135. [CrossRef] [PubMed]

146. Burteau, C.C.; Verhoeye, F.R.; Mols, J.F.; Ballez, J.S.; Agathos, S.N.; Schneider, Y.J. Fortification of a protein-free cell culture medium with plant peptones improves cultivation and productivity of an interferon-gamma-producing CHO cell line. In Vitro Cell Dev. Biol. Anim. 2003, 39, 291-296. [CrossRef] 